\section{Prevalence and characterisation of shigatoxigenic Escherichia coli isolated from beef cattle fed with prebiotics}

\author{
Luca Grispoldi, Filippo Bertero, \\ Serena Franceschini, \\ Francesco Mastrosimone, Paola Sechi, \\ Maria Francesca Iulietto, \\ Margherita Ceccarelli, \\ Beniamino Terzo Cenci-Goga \\ Department of Veterinary Medicine, \\ University of Perugia, Italy
}

\section{Abstract \\ Ten Holstein Friesian calves were} divided into two groups of five: one group was given prebiotics in their food, while the other group served as the control group. Every two weeks from birth up to 18 months, samples of feces were taken from the rectal ampulla to determine the concentration of E. coli. At each sampling session, three aliquots per sample were collected. The arithmetic mean was calculated and all values (converted into logs) were analysed with GraphPad InStat for analysis of variance, followed by the Tukey-Kramer test. A total of 69 E. coli strains were detected, 29 (42.03\%) from treated animals and $40(57.97 \%)$ from the control group. The isolates were analysed by PCR for the presence of the stx-1, stx-2, hly and eae genes and by the Kirby Bauer test for susceptibility to the most commonly used antimicrobials in cattle breeding. Hierarchical clustering of the isolates was done using Ward's method. Thirty samples were positive for the stx-1 gene, 18 for stx2, 12 for both $s t x-1$ and $s t x-2,8$ for $h l y$, and 10 for eae. $4.3 \%$ were resistant to sulfamides, $8.6 \%$ to tetracycline, $1.4 \%$ to gentamicin, $94.6 \%$ to cephalothin, $2.8 \%$ to chloramphenicol, $13 \%$ to ampicillin, $13 \%$ to amoxicillin/clavulanic acid, $7.2 \%$ to sulphonamides, $4.3 \%$ to ceftriaxone, $5.7 \%$ to nalidixic acid, $34.7 \%$ to ticarcillin, $88.5 \%$ to erythromycin, and $5.7 \%$ to streptomycin. The isolates from the samples taken from day 210 to day 300 were grouped into a single cluster. Bacteriological examinations showed a reduction in the concentration of $E$. coli in the feces of the treated animals compared to the control group. The presence of strains with shigatoxigenic Escherichia coli virulence profiles and the reduction of these in the treated animal group demonstrated that diet can play an important role in reducing $E$. coli prevalence in cattle.

\section{Introduction}

Shigatoxigenic Escherichia coli (STEC) are pathogenic bacteria that can cause diarrhea, hemorrhagic colitis and hemolyticuremic syndrome (HUS) in humans. Although infections caused by enterohemorrhagic $E$. coli are often associated with serotype O157:H7, other serotypes may also be involved and may be highly virulent (Lior, 1994; Brooks et al., 2005; Bonardi et al., 2007). Cattle are considered the main reservoir for STEC pathogenic for humans (Milnes et al., 2006; Jay et al., 2009). Most infections are attributed to the ingestion of water or foods contaminated by bovine feces (in particular raw vegetables, raw and undercooked meat and dairy products obtained from unpasteurised milk) (Caprioli et al., 2005). The virulence of the STEC strains is linked to the production of certain virulence factors such as intimin (coded by the eaeA gene) and hemolysin (coded by the $h l y A$ gene), but above all to the production of Shiga toxins (coded by the stx 1 and stx 2 genes) (Cheasty et al., 1983; Griffin et al., 1995). These are toxins made up of one A subunit, with enzymatic activity, and five identical B subunits, which bind to a specific glycolipid on the membrane of the host cell (globotriaosylceramide, Gb3, which is found in the intestinal villi and renal endothelial cells). Once the A subunit has been internalised, it is split into two molecules, and fragment A1 binds to ribosomal RNA 28S, blocking protein synthesis (Karmali et al., 2003). The toxins are produced in the colon (Naylor et al., 2003) and are carried by the blood to the arterial endothelial cells of the kidney and the large intestine, which in humans are rich in $\mathrm{Gb} 3$ receptors, causing serious damage to those vascular districts (Brigotti et al., 2006). In addition, these toxins induce apoptosis in intestinal epithelial cells; the resulting destruction of the intestinal villi causes a decrease in absorption, with a relative increase in fluid secretion (Salminen et al., 1998). Shiga toxins also stimulate the production of cytokines, in particular TNF and interleukin6, which, among other effects, cause an increase in Gb3 expression (Poli et al., 2005). To date, most of the efforts to avoid infection in humans have been concentrated on minimising the risk of fecal contamination of carcass at slaughter (Colavita, 2012). To this end, it is equally important to reduce prevalence and excretion of pathogenic $E$. coli in calves by developing alternative methods to the use of antimicrobials, so as to minimise the risk of developing antimicrobial resistance. One of these alternative methods is the addition of
Correspondence: Luca Grispoldi, Department of Veterinary Medicine, University of Perugia, Via S. Costanzo, 4, 06126 Perugia, Italy. Tel: +39.342 .8391290 - Fax +39.075.585 .7976. E-mail: grisluca@outlook.it

Key words: E. coli, STEC, Cattle, Prebiotics.

Conflict of interest: I, LC, certify that all relevant financial, personal, or professional relationships with other people or organisations that pose a conflict of interest, that could reasonably be perceived as posing a conflict of interest, or that could potentially influence or bias my work described in the manuscript have been fully and truthfully disclosed in the space below. Such relationships include affiliations and financial involvement within the past 3 years and in the foreseeable future (as speci-fied below) with any organisation or entity that has financial interests in or financial conflicts with the subject matter or materials discussed in the manuscript.

Received for publication: 27 July 2017.

Revision received: 13 October 2017

Accepted for publication: 14 October 2017.

This work is licensed under a Creative Commons Attribution-NonCommercial 4.0 International License (CC BY-NC 4.0).

(C) Copyright L. Grispoldi, et al., 2017 Licensee PAGEPress, Italy

Italian Journal of Food Safety 2017; 6:6958 doi:10.4081/ijfs.2017.6958

prebiotics in the cattle's diet. According to Roberfroid et al. (1998), a prebiotic is a selectively fermented ingredient that allows specific changes, both in the composition and/or activity in the gastrointestinal microflora that confers benefits upon host well being and health. They can also induce the growth or activity of beneficial microorganisms that can inhibit other species such as E. coli (Gibson et al., 1995).

The present study analyses the effect of the administration of prebiotics in the diet of calves on the prevalence of $E$. coli in the feces. The strains with STEC phenotypic traits were tested for the presence of eaeA, hlyA, stx 1 and stx 2 genes by PCR (Schurman et al., 2000; Karama and Gyles, 2013; EFSA, 2017) and the susceptibility profile to the antimicrobials most commonly used in buiatrics was analysed by agar diffusion test.

\section{Materials and Methods}

\section{Experimental design}

For this study, 10 male Holstein Friesian calves for beef production were selected 
using simple random sampling from a list of animal-identification numbers to ensure a representative sample of animals from the farm. The farm, where the entire production cycle took place, was located in central Italy. The animals were randomly divided into two groups: the experimental group consisting of 5 calves was given prebiotics, while the 5 calves of the control group were not given anything besides their normal feed. The major components of the prebiotics used were calcium carbonate, alfalfa meal, wheat middings, extract of Yucca schidigera and yeasts. For contractual and privacy reasons the exact composition cannot be revealed.

For the first month, the treated calves group was given $3 \mathrm{~g}$ per head a day of prebiotic A, administered orally and in a uniform and homogeneous manner to all the animals. Subsequently, a second prebiotic (prebiotic B) was administered, which was mixed with the unifeed, to maximise the homogeneous distribution of the active ingredient in the feed. The dosage of the second prebiotic was $4 \mathrm{~g}$ per head a day. Double dosage was used for the first month according to the producer's guidelines.

\section{Fecal sampling and microbiological analysis}

Fecal samples were taken at two-week intervals directly from the rectal ampulla with sterile gloves, transferred to sterile bags and sent to the laboratory in a refrigerated container.

In order to detect the coliform presence each sample of feces was diluted 1:10 in peptonated water (PW Difco, Detroit, MI, USA) and homogenised in Stomacher 400 (PBI International, Milan, Italy). Subsequently, additional 1:10 dilutions were made using Maximum Recovery Diluent (MRD, Oxoid, Basingstoke, Hampshire, UK) to obtain 10-fold diluitions. Dilutions were inoculated in triplicate on Violet Red Bile Lactose Agar (VRBL, Oxoid) using the spread plate technique and incubated at 35 - $37^{\circ} \mathrm{C}$ for $18-24$ hours. Colonies were then counted on all the plates, using a colony count viewer (Petri light, PBI, Milan) and colony counter pen (Colony Count, PBI, Milan) (Sechi et al., 2012). All values were converted into logs and the arithmetic mean was calculated for each sampling. All values were analysed with Graph Pad In Stat, version 3.0b for Mac OS X; the graphs were obtained with Graph Pad Prism version 6.0d for Mac OS X (Feng et al., 2007).

Some lactose fermenting colonies were harvested from the VRBL and seeded on MacConkey Sorbitol Agar (MCS, Oxoid), incubated at $37^{\circ} \mathrm{C}$ for 18 hours. All sorbitolnegative colonies were seeded on TBX (Tryptone Bile X-glucuronide Medium, Oxoid) at $37^{\circ} \mathrm{C}$ for 24 hours to evaluate the presence of beta-glucuronidase, in BGBB (Brilliant Green Bile Broth 2\%, Oxoid) with a Durham tube at $44^{\circ} \mathrm{C}$ for 24 hours, and in peptonate water at $44^{\circ} \mathrm{C}$ for $24 \mathrm{~h}$ for confirmation of $E$. coli (growth at $44^{\circ} \mathrm{C}$ with gas and indole production). All the colonies of presumed sorbitol-negative $E$. coli on the basis of the tests described, for a total of 69 bacterial strains, were transferred to TSB (Tryptone Soya Broth, Oxoid) and frozen at $-80^{\circ} \mathrm{C}$ until needed for the subsequent analyses (Cenci Goga et al., 2005; Rosmini et al., 2011).

\section{Genetic characterisation}

The strains of Escherichia coli were thawed and aerobically cultivated in Nutrient Broth (NB, Oxoid) at $37^{\circ} \mathrm{C}$ for 24 hours. Extraction of the DNA was then carried out by boiling, a protocol defined in previous studies by Cenci Goga et al. (2004): in short, samples of the colonies were diluted in $1 \mathrm{ml}$ of PBS (phosphate buffered saline). The suspension was centrifuged at $13,000 \mathrm{rpm}$ for 5-7 min. and the supernatant was eliminated. The pellet containing the bacteria was then resuspended in $100 \mu \mathrm{L}$ of sterile distilled water and boiled for 10 minutes. The DNA was recovered after centrifugation at 13,000 rpm for 5-7 min., then stored at $-20^{\circ} \mathrm{C}$ until amplification.

DNA amplification was conducted on a volume of $25 \mu \mathrm{L}$ using: $12.5 \mu \mathrm{L}$ of RED Taq (10 mM of Tris $\mathrm{HCl} \mathrm{pH} 8.3,50 \mathrm{mM} \mathrm{KCl}, 1.5$ $\mathrm{mM} \mathrm{MgCl} 2,0.001 \%$ of gelatin, $0.2 \mathrm{mM}$ of each deoxyribonucleoside triphosphate), 0.5 microL ( 1 microM) of each primer, $5 \mu \mathrm{L}$ of extracted DNA, $6.5 \mu \mathrm{L} \mathrm{H} 2 \mathrm{O}$. The presence of the stx 1, stx2, eaeA and hly genes was investigated. The primers and the amplification conditions used are given in Table 1 . The PCR reaction was carried out in a Thermocycler Gene Amp, PCR System, 9700 Gold (Applied Biosystem, Foster City, CA, USA). The amplifications were analysed by electrophoretic run on $1.5 \%$ agarose gel containing ethidium bromide $(0.5 \mu \mathrm{g} / \mathrm{ml}) ; 10$ $\mu \mathrm{L}$ of each PCR sample was loaded with 2 $\mu \mathrm{L}$ of $6 \mathrm{X}$ loading buffer (Fermentas-VWRItaly) and $5 \mu \mathrm{L}$ of marker-PCR as reference DNA (Fermentas- VWR-Italy); the run was carried out at a voltage of $100 \mathrm{~V}$ for about 1 hour in TBE 10X (Trizma base, boric acid, EDTA $0.5 \mathrm{M} \mathrm{pH} \mathrm{8).} \mathrm{At} \mathrm{the} \mathrm{end} \mathrm{of} \mathrm{the} \mathrm{run} \mathrm{the}$ bands were viewed with the UV transilluminator (Fotodine 3-3102 Celbio, Milan, Italy) (Paton et al., 1998).

\section{Antimicrobial resistance}

The strains were thawed and cultured in Brain Heart Infusion Broth (BHI, Oxoid) at $35-37^{\circ} \mathrm{C}$ for 24 hours. Part of the culture broth was inoculated into $6 \mathrm{ml}$ of $0.9 \%$ sterile physiological saline solution until reaching a turbidity of 2 McFarland. Using a sterile swab the solution thus obtained was seeded on Muller-Hinton Agar (Oxoid). Disks containing antimicrobials (Oxoid) were placed over it, and the plates were incubated at $35-37^{\circ} \mathrm{C}$ for $18-24$ hours in aerobiosis. The antimicrobials tested were: compound sulphonamides $\quad 300 \quad \mathrm{mg}$, sulphamethoxazole/trimethoprim $25 \mathrm{mg}$, cyprofloxacin $5 \mathrm{mg}$, nalixidic acid $30 \mathrm{mg}$, enrofloxacin $5 \mathrm{mg}$, chloramphenicol $30 \mathrm{mg}$,

Table 1. Primers and amplification conditions used.

\begin{tabular}{|c|c|c|c|c|}
\hline Target gene & Nucleotidic sequence $\left(5^{\prime}-3^{\prime}\right)$ & Amplification (bp) & Mix conditions & Amplification programme \\
\hline STX1 & $\begin{array}{l}\text { ACACTGGATGATCTCAGTGG } \\
\text { CTGAATCCCCCTCCATTATG }\end{array}$ & 614 bp & $\begin{array}{l}\text { Volume: } 25 \mu \mathrm{L} ; \\
\text { Dna: } 5 \mu \mathrm{L} \text {; water: } 6.5 \mu \mathrm{L} ; \\
\text { Primer F-R: } 0.5 \mu \mathrm{L} ; \\
\text { MixTaq: } 12.5 \mu \mathrm{L}\end{array}$ & $\begin{array}{c}95^{\circ} \mathrm{C} \times 3^{\prime} ; 95^{\circ} \mathrm{C} \times 20^{\prime \prime} ; 58^{\circ} \mathrm{C} \times 40^{\prime \prime} ; \\
\times 35 \text { cycles } 72^{\circ} \mathrm{C} \times 1,5^{\prime} ; \\
72^{\circ} \mathrm{C} \times 5^{\prime}\end{array}$ \\
\hline STX2 & $\begin{array}{l}\text { CCATGACAACGGACAGCAGTT } \\
\text { CCTGTCAACTGAGCAGCACTTTG }\end{array}$ & 779 bp & $\begin{array}{c}\text { Volume: } 25 \mu \mathrm{L} \text {; Dna: } 5 \mu \mathrm{L} ; \\
\text { water: } 6.5 \mu \mathrm{L} ; \text { Primer F-R: } 0.5 \mu \mathrm{L} \text {; } \\
\text { MixTaq: } 12.5 \mu \mathrm{L}\end{array}$ & $\begin{array}{c}95^{\circ} \mathrm{C} \times 3^{\prime} ; 95^{\circ} \mathrm{C} \times 20^{\prime \prime} ; 58^{\circ} \mathrm{C} \times 40^{\prime \prime} ; \\
\times 35 \text { cycles } 72^{\circ} \mathrm{C} \times 1.5^{\prime} ; \\
72^{\circ} \mathrm{C} \times 5^{\prime}\end{array}$ \\
\hline EAEA & $\begin{array}{l}\text { GTGGCGAATACTGGCGAGACT } \\
\text { CCCCATTCTTTTTCACCGTCG }\end{array}$ & $890 \mathrm{bp}$ & $\begin{array}{c}\text { Volume: } 25 \mu \mathrm{L} ; \text { Dna: } 5 \mu \mathrm{L} ; \\
\text { water: } 6.5 \mu \mathrm{L} ; \text { Primer F-R: } 0.5 \mu \mathrm{L} \text {; } \\
\text { MixTa: } 12.5 \mu \mathrm{L}\end{array}$ & $\begin{array}{c}95^{\circ} \mathrm{C} \times 3^{\prime} ; 95^{\circ} \mathrm{C} \times 20^{\prime \prime} ; 58^{\circ} \mathrm{C} \times 40^{\prime \prime} ; \\
\times 35 \text { cycles } 72^{\circ} \mathrm{C} \times 1.5^{\prime} ; \\
72^{\circ} \mathrm{C} \times 5^{\prime}\end{array}$ \\
\hline$H L Y$ & $\begin{array}{l}\text { GCATCATCAAGCGTACGTTCC } \\
\text { AATGAGCCAAGCTGGTTAAGCT }\end{array}$ & $534 \mathrm{bp}$ & $\begin{array}{c}\text { Volume: } 25 \mu \mathrm{L} ; \text { Dna: } 5 \mu \mathrm{L} \text {; } \\
\text { water: } 6.5 \mu \mathrm{L} ; \text { Primer F-R: } 0.5 \mu \mathrm{L} \text {; } \\
\text { MixTaq: } 12.5 \mu \mathrm{L}\end{array}$ & $\begin{array}{c}95^{\circ} \mathrm{C} \times 3^{\prime} ; 95^{\circ} \mathrm{C} \times 1^{\prime} ; 58^{\circ} \mathrm{C} \times 1^{\prime} ; \\
\times 35 \text { cycles } 72^{\circ} \mathrm{C} \times 1^{\prime} ; \\
72^{\circ} \mathrm{C} \times 10^{\prime}\end{array}$ \\
\hline
\end{tabular}


amoxycillin/clavulanic acid $30(20+10) \mathrm{mg}$, ampicillin $10 \mathrm{mg}$, cefotaxime $30 \mathrm{mg}$, ceftriaxone $30 \mathrm{mg}$, cephalothin $30 \mathrm{mg}$, ticarcillin $75 \mathrm{mg}$, tetracycline $30 \mathrm{mg}$, amikacyn $30 \mathrm{mg}$, gentamicin $10 \mathrm{mg}$, kanamycin $30 \mathrm{mg}$, neomycin30 mg, streptomycin $10 \mathrm{mg}$, erythromycin $15 \mathrm{mg}$, colistin $10 \mathrm{mg}$. At the end of the incubation, the diameters of the growth inhibitory zones were measured, and these were interpreted according to specific tables (CLSI, 2011), where the bacterium is classified as sensitive, intermediate or resistant. Hierarchical clustering of the isolates was performed using Ward's method by means of Hierarchical Clustering - Software.

\section{Results and Discussion}

The excretion of coliforms progressively decreased over time in both groups, ranging from $8 \log \mathrm{cfu} / \mathrm{g}$ to about $6 \log \mathrm{cfu} / \mathrm{g}$, stabilising at around four months of age. The decrease was related to the normal development of the calf intestinal microbiota. From Figure 1 it can be seen how the treated group had lower average values than the control group, although the difference was not statistically significant. The excretion of sorbitol-negative bacteria also followed a similar trend; at T0 both groups had a value of about $7 \mathrm{log} \mathrm{cfu} / \mathrm{g}$, which dropped to $5.3 \mathrm{log}$ $\mathrm{cfu} / \mathrm{g}$ in the control group and $4.7 \mathrm{log} \mathrm{cfu} / \mathrm{g}$ in the treated group (Figure 2). Twenty-nine $(42 \%)$ of the $69 \mathrm{E}$. coli strains were isolated from the treated group, while 40 (58\%) were isolated from the control group. The molecular characterisation of the virulence profile obtained by PCR showed that out of the 29 strains isolated from the treated animals, $11(37.93 \%)$ were positive for the stx 1 gene, $8(27.59 \%)$ for $s t x 2,4(13.79 \%)$ for $h l y A, 5$ (17.24\%) for eae $A$ and 6 (20.69\%) for both stx 1 and stx 2 . Of the 40 strains isolated from the control group, $19(47.5 \%)$ were positive for $s t x 1,10(25 \%)$ for $s t x 2,8(20 \%)$ for $h l y A, 8(20 \%)$ for eaeA and $6(15 \%)$ for both stxl and stx2. A lesser prevalence can be found of $E$. coli with phenotypic characteristics attributable to serotypes pathogenic for humans in cattle treated with prebiotics. The difference between the two groups was not statistically significant. The prevalence of stxl, hlyA and eaeA was also lower in treated calves, while $s t x 2$ was similar in both groups. The antibiogram data are shown in Table 2. All the strains were sensitive to ciprofloxacin, cefotaxime, kanamycin and amikacin. In the case of erythromycin, no strains were found to be sensitive. This confirms the intrinsic resistance of $E$. coli to this antimicrobial, linked to the mutation of the L4 and L22

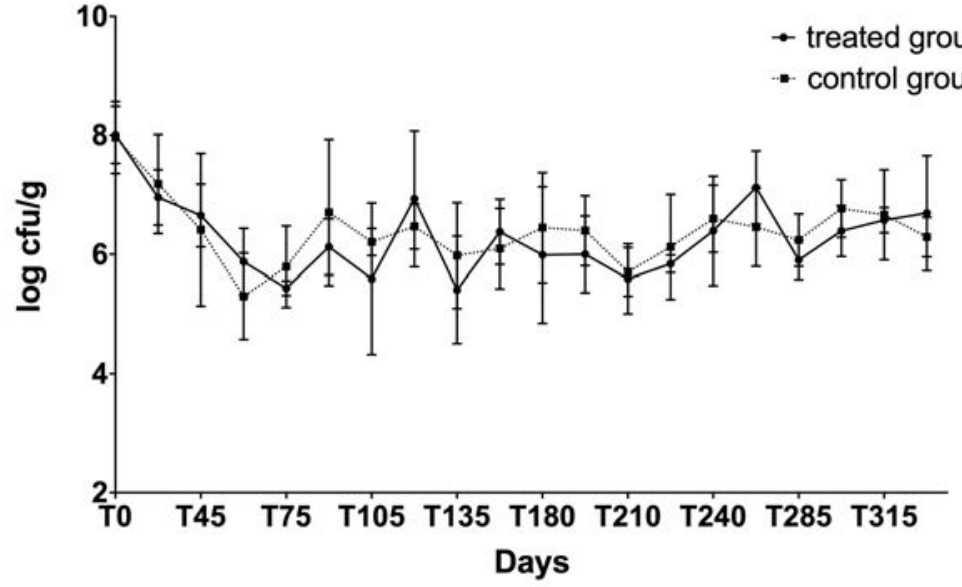

Figure 1. Trend of the excretion of coliforms in the stools.

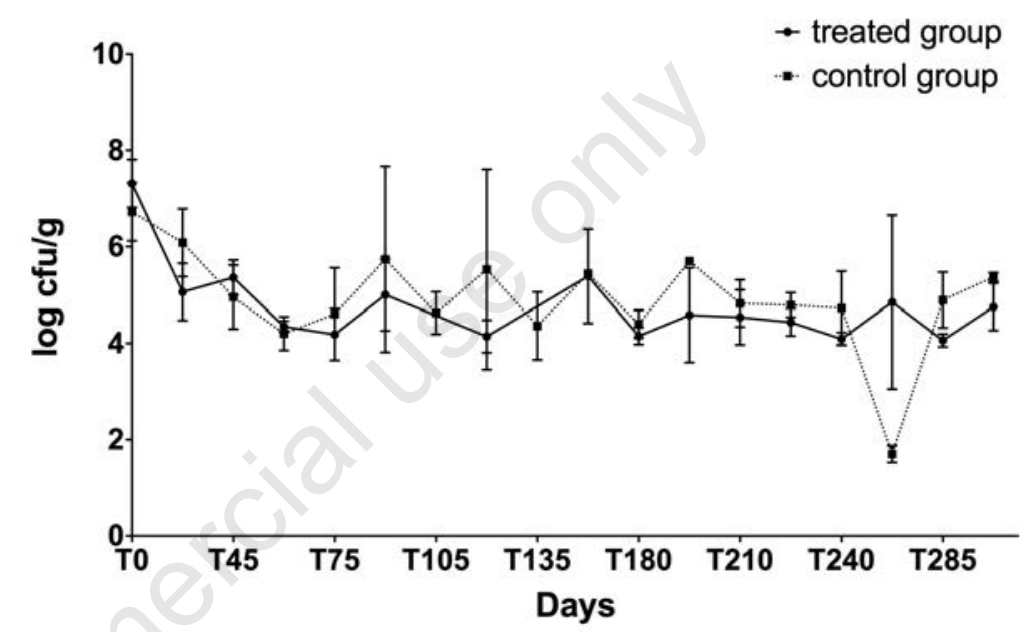

Figure 2. Trend of the excretion of sorbitol-negative Escherichia coli.

Table 2. Antibiogram data, expressed as percentage.

\begin{tabular}{lccc}
\hline Antimicrobial & Resistant (\%) & Intermediate (\%) & Sensitive (\%) \\
Compound sulphonamides (S3) & 7.2 & 0 & 92.8 \\
Sulphamethoxazole/trimethoprim (SXT) & 4.3 & 0 & 95.7 \\
\hline Cyprofloxacin (CIP) & 0 & 0 & 100 \\
Nalixidic acid & 5.7 & 0 & 94.3 \\
\hline Enrofloxacin (ENR) & 0 & 4 & 96 \\
Chloramphenicol (C) & 2.8 & 0 & 97.2 \\
\hline Amoxycillin/Clavulanic Acid (AMC) & 13 & 4.3 & 82.7 \\
Ampicillin (AMP) & 13 & 21.7 & 65.3 \\
\hline Cefotaxime (CTX) & 0 & 0 & 100 \\
Ceftriaxone (CRO) & 4.3 & 8.6 & 87.1 \\
\hline Cephalothin (KF) & 94.6 & 4 & 1.4 \\
Ticarcillin (TIC) & 34.7 & 1.4 & 63.9 \\
\hline Tetracycline (TET) & 8.6 & 15.9 & 75.5 \\
Amikacyn (AK) & 0 & 0 & 100 \\
\hline Gentamicin (CN) & 1.4 & 0 & 98.6 \\
Kanamycin (K) & 0 & 0 & 100 \\
\hline Neomycin (N) & 0 & 18.8 & 81.2 \\
Streptomycin (S) & 5.7 & 28.9 & 65.4 \\
\hline Erythromycin (E) & 88.5 & 11.5 & 0 \\
Colistin & 0 & 10.1 & 89.9 \\
\hline & & & \\
\hline
\end{tabular}




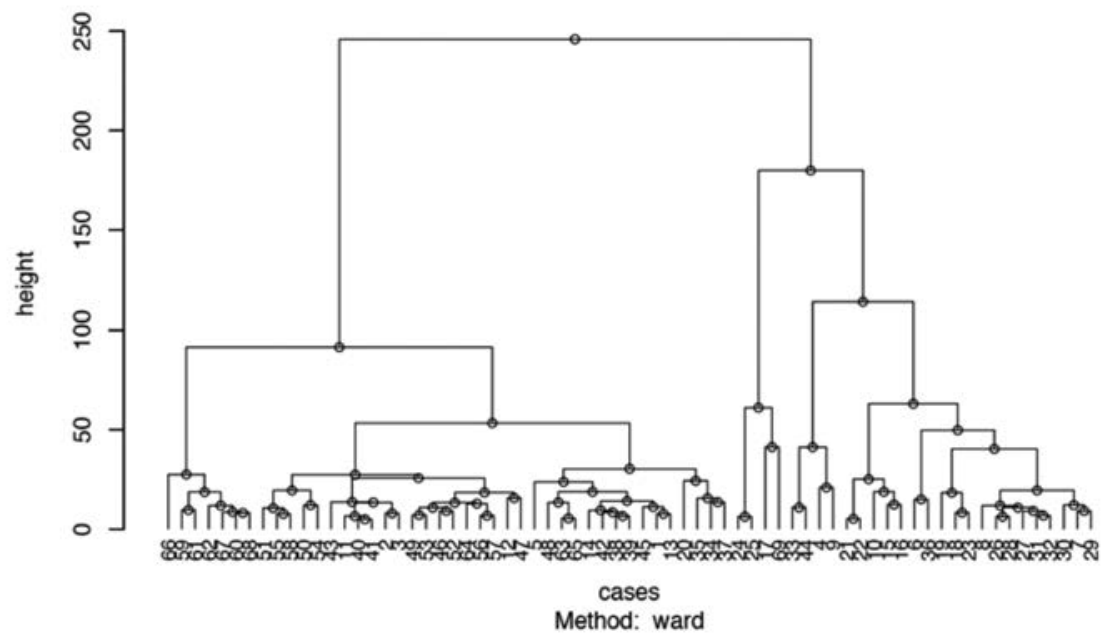

Figure 3. Hierarchical clustering of the isolates.

proteins of the ribosomal subunits (Wittman and Stöffler, 1973).

E. coli strains showed a lower resistance to tetracycline $(8.6 \%)$ than that for ampicillin (13\%), unlike other studies (Mainda et al., 2015).

The hierarchical clustering shows that there is a clear distinction between the strains isolated after 210 days of life of the calves, which are grouped into a single cluster, compared to all the others (Figure 3). This fact may be related to the physiological change occurring in the calf immune system at about six months of age, with the end of maternal immunity and an increase in the immunocompetence of animals, where the intestinal microbiota could change. However, no distinctions in clusters were observed among the strains isolated from the treated calves compared to those isolated from the control group.

\section{Conclusions}

In recent years, human infection caused by $E$. coli has become frequent. An important challenge will be to more definitely identify and characterise the strains, which will allow a more thorough surveillance of the prevalence of the bacteria in animal populations, assessment of the importance of these bacterial species in humans' infections and development of effective on-farm control strategies. In this context, the prebiotics use can be a great strategy to reduce the shedding and consequently the presence of these pathogens on the farm reducing thus the occurrence of infections in humans.

The data obtained show how the administration of prebiotics in the diet of calves may decrease the excretion of coliforms, and more specifically the prevalence of shigatoxigenic E. coli. The development of formulas aimed at maximising this effect is of the greatest importance to minimise the risk of transmitting food-borne diseases for the final consumer. Moreover, prebiotics, like other groups of food additives that can modify the composition of the intestinal flora of cattle, are very important tools also because they can be used instead of antimicrobials. The misuse of antimicrobials has in fact contributed to the development of resistance in very dangerous pathogenic bacteria involved in episodes of illnesses affecting

\section{References}

Bonardi S, Foni E, Chiapponi C, Salsi A, Brindani F, 2007. Detection of verocyto toxin-producing Escherichia coli serogroups $\mathrm{O} 157$ and $\mathrm{O} 26$ in the cecal content and lymphatic tissue of cattle at slaughter in Italy. J Food Protect 70:1493-7.

Brigotti M, Caprioli A, Tozzi AE, Tazzari PL, Ricci F, Conte R, Carnicelli D, Procaccino MA, Minelli F, Ferretti AV, Paglialonga F, Edefonti A, Rizzoni G, 2006. Shiga toxins present in the gut and in the polymorphonuclear leukocytes circulating in the blood of children with hemolytic-uremic syndrome. J Clin Microbiol 44:313-7.

Brooks JJ, Sowers EG, Wells JG, Greene KD, Griffin PM, Hoekstra RM, Strockbine NA, 2005. Non-O157 Shiga the consumer. toxin producing Escherichia coli infections in the United States, 19832002. J Infect Dis 192:1422-9.

Caprioli A, Morabito S, Grugere H, Oswald E, 2005. Enterohaemorragic Escherichia coli: emerging issues of virulence and models of trasmission. Vet Res 36:289311.

Cenci Goga BT, Crotti S, Costarelli C, Rondini C, Karama M, Bennett P, 2004. Detection of tet(M) gene from raw milk by rapid DNA extraction followed by a two-step PCR with nested primers. J Food Protect 67:2833-8.

Cenci Goga BT, Ortenzi R, Codega de Oliveira A, Bartocci E, Vizzani A, 2005. Patogenesi e diagnostica di laboratorio delle infezioni da Escherichia coli enteroemorragici. Praxis Vet 26:2-11.

CLSI, 2011. Performance standards for antimicrobial susceptibility testing. $21 \mathrm{st}$ informational supplement CLSI M100S21 ed. - Clinical and Standards Laboratory Institute, Wayne, PA, USA.

Colavita G, 2012. Igiene e tecnologie degli alimenti di origine animale. Le Point Veterinaire Italie Srl, Milan, Italy.

Cheasty T, Rowe B, 1983. Antigenic relationship between the enteroinvasive Escherichia coli $\mathrm{O}$ antigens $\mathrm{O} 28 \mathrm{ac}$, O112ac, O124, O136, O143, O144, $\mathrm{O} 152$ and $\mathrm{O} 164$ and Shigella $\mathrm{O}$ antigens. J Clin Micobiol 17:681-4.

EFSA, 2017. The European Union summary report on antimicrobial resistance in zoonotic and indicator bacteria from humans, animals and food in 2015. EFSA J 15:4694.

Feng P, Weagant S, Grant M, 2007. Enumeration of Escherichia coli and the Coliform Bacteria. Bacteriological Analytical Manual (VIII ed.). Available from:

https://www.fda.gov/Food/FoodScience Research/LaboratoryMethods/ucm0649 48.htm

Gibson GR, Roberfroid MB, 1995. Dietary modulation of the human colonic microbiota: introducing the concept of prebiotic. J Nutr 25:1401-12.

Griffin PM, 1995. Escherichia coli O157:H7 and other enterohemorrhagic Escherichia coli. Infection of the gastrointestinal tract. Raven Press, New York, NY, USA, pp. 739-762.

Jay JM, Loessner MJ, Golden DA, 2009. Microbiologia degli alimenti. Springer, Amsterdam, The Netherlands.

Karama M, Gyles CL, 2013. Virulence profiling of shigatoxin-producing Escherichia coli O111: NM isolates from cattle. Appl Environ Microbiol 79:41645.

Karmali MA, Mascarenhas M, Shen S, 
Zieben K, Johnson S, Reid-Smith R, Isaac-Renton J, Clark C, Rahn K, Kaper JB, 2003. Association of genomic O island 122 of Escherichia coli EDL 933 with verocytotoxin-producing Escherichia coli seropathotypes that are linked to epidemic and/or serious disease. J Clin Microbiol 41:4930-40.

Lior H, 1994. Escherichia coli O157:H7 and verotoxigenic Escherichia coli (VTEC). Dairy Food Environ Sanit 14:378-82.

Mainda G, Bessell PR, 2015. Prevalence and patterns of antimicrobial resistence among Escherichia coli isolated from Zambian dairy cattle across different production systems. Sci Rep 5:12439.

Milnes AS, Pritchard GC, Sprigings K, Futter R, Willshaw GA, 2006. Verocytotoxin-producing E. coli O26 infection in calves. Vet Rec 159:159.

Naylor SW, Low JC, Besser TE, Mahajan A, Gunn GJ, Pearce MC, McKendrick IJ, Smith DGE, Gally DL, 2003. Lymphoid follicle-dense mucosa at the terminal rectum is the principal site of colonization. Infect Immun 71:1505-12.

Paton AW, Paton JC, 1998. Detection and characterization of Shiga toxigenic Escherichia coli by using Multiplex PCR assay for stx1, stx2, eaeA, enterohemorragic E. coli hlyA, rbf O111 and rbf O157. J Clin Microbiol 36:598602.

Poli G, Cocilovo A, Dall'Ara P, Martino PA, Ponti W, 2005. Microbiologia ed immunologia veterinaria, II ed. UTET Ed., Turin, Italy.

Roberfroid MB, 1998. Prebiotics and synbiotics: concepts and nutritional properties. Brit J Nutr 80:197-202.

Rosmini R, 2011. Sviluppo di metodi per la ricerca di VTEC non-O157 ed indagini sulla prevalenza di Escherichia coli produttori di shigatossine in allevamenti bovini. Carni e Latte.

Salminen S, Bouley C, Boutron-Ruault MC,
Cummings JH, Franck A, Gibson GR, Isolauri E, Moreau MC, Roberfroid M, Rowland I, 1998. Functional food science and gastrointestinal physiology and function. Brit J Nutr 80:S147-71.

Sechi P, Cambiotti V, Parmegiani S, Baldinelli C, Iulietto MF, Cenci Goga BT, 2012. Isolation of Escherichia coli from lymphnodes of bovine carcasses and detection of hlyA gene with PCR. Ital J Food Safety 5:823.

Schurman RD, Harihran H, Heaney SB, Rahn K, 2000. Prevalence and characteristics of shiga toxin producing Escherichia coli in beef cattle slaughtered on Prince Edward Island. J Food Protect 63:1583-6.

Wittmann HG, Stöffler G, 1973. Biochemical and genetic studies on two different types of erythromycin resistant mutants of Escherichia coli with altered ribosomal proteins. Mol Gen Genet 127:175-89. 